\title{
THE PANDEMIC OF COVID-19 - A CATALYST FOR CHANGES IN THE COUNTRIES OF EAST CENTRAL EUROPE
}

Kinga WOJTAS, PhD

Cardinal Stefan Wyszynski University in Warsaw, Poland

k.wojtas-jarentowska@uksw.edu.pl

Katarzyna WALECKA, PhD

Cardinal Stefan Wyszynski University in Warsaw, Poland

k.grzybowska-walecka@,uksw.edu.pl

\begin{abstract}
The pandemic of Covid-19 has been an unprecedented challenge to the majority of countries in the world. This article examines whether COVID-19 has strengthened or weakened the previously chosen path of development in four countries in Central and Eastern Europe - Slovakia, the Czech Republic, Hungary, Ukraine, and Moldova. The selected countries represent different transformation paths taken after the collapse of communism and allow for showing various reactions of governments to the Covid- 19 crisis. Therefore, we analyze the pandemic's effect on three major components of the developmental process - political, social, and economic and check whether COVID-19 has caused any changes in these three spheres. Also, we scrutinized the scope of the measures implemented by governments and their impact on their development paths. We found that while in the Czech Republic and Slovakia, the liberal democracy model has not been questioned, in Hungary, the earlier tendencies of backsliding from democracy have deepened. In the countries which are in the process of democracy-building - Moldova and Ukraine - the pandemic has not significantly affected the intensity of violating its principles, as they are still weakly established. Thus, the analysis of the first wave of the Covid-19 pandemic showed that it was not a catalyst for the change but tended to deepen and strengthen trends that existed before.
\end{abstract}

Keywords: Covid-19, East Central Europe, development path, trust in government, democracy.

\section{Introduction}

The Post-Soviet region has been undergoing intense transformations since the 1990s. The changes included the abandoning of so-called real socialism/people's democracy states, with their centrally steered and planned economies. The countries of East Central Europe immediately declared their intent to "return to Europe" - which posed a daunting dual task for those which endeavoured to undertake the journey: the transformation of both the political and economic systems (Wagener, 2001, p.10). Thus, liberal democracies and free market economies were chosen 
as the ultimate goal of the implemented changes. Opinions on the nature of those changes varied. While most academics saw them as modernization, at the same time one could hear experts claiming that they were only imitational changes, consisting in copying solutions and creating falsifications of Western European solutions. As Stark and Bruszt argue "neo-liberalism sees blueprints for the imitation of market institutions as the road to progress" but the communist past can be a burden to marketization and democratization (Stark, Bruszt, 1998 p. 5). Therefore, the institutional contexts and identities of political actors are important factors in transition. However, the argument can be heard that the transformation process did not concentrate sufficiently on social solidarity, democratic participation, public benefit or respect for individuals and their rights, and that the focus was on the impressive facade, not on the supporting structure (Krasnodębski, 2005). Thus, it is justifiable to examine the effect of a global crisis - such as the COVID-19 pandemic on the development model adopted in the region. If the thesis regarding the superficiality of the transformation changes is true, the shock caused by the epidemic would have to be noticeable. In this article we argue that the pandemic caused by Covid-19 has become a decisive moment in the development model in East Central European countries. The economic effects may give rise to a political crisis, which may be the origin of a profound transformation of the national political system (Kriesi, Hutter, 2019).

In this paper we will examine whether COVID-19 has strengthened or weakened the previously-chosen path of development in some countries of the region. Therefore, we will analyse the effect of the pandemic on three major components of the process - political, social and economic - and we will check whether COVID-19 has caused any changes in these three spheres. Furthermore we will analyse the scope of the measures implemented by governments and their impact on their development paths. The cases which will be analysed and compared belong to the broadly-defined former communist countries ${ }^{1}$ - Slovakia, the Czech Republic, Hungary, Ukraine and Moldova. Each of the selected countries adopted a different transformation path and for years remained a transformation leader in their categories: the Czech Republic and Hungary in the postcommunist area, and Moldova and Ukraine in the Post-USSR area. Slovakia, on the other hand,

\footnotetext{
${ }^{1}$ They include both former Soviet republics - Ukraine and Moldova, and selected countries that historically belonged to the socalled 'Socialist states in the Soviet sphere' - Czechoslovakia (and after its break-up - the Czech Republic and Slovakia) and Hungary (Marciniak, 2004)
} 
after the period of Mečiar rule in the 1990s - described as a "democratic dictatorship" - joined the leaders' group in 1998.

Therefore, in the first part of this paper we reconstruct the approaches to development models in Central Eastern Europe and single out their components. Next we analyse the trajectories of transformation in the political, social and economic spheres and the measures introduced by the governments to mitigate the impact of the COVID-19 pandemic. This will allow us to assess the potential changes that may occur (or be occurring) as an effect of the crises.

\section{Development model in Central Eastern Europe}

As Claus Offe noted, in the 1960s and 1970s it was assumed (under the convergence theories) that the communist and the capitalist regions will come nearer to each other. i.e. that we would witness an assimilation of these different forms. Over time it became more likely that the East, as a result of its many years of mistakes and negligence "would collapse" (the spilled oil approach) and would join the Western world (Offe, 1997). The process of transforming the postcommunist area and the accompanying challenges concerning the development of democracy became apparent, and the question became the extent of deep changes required. Three levels of the state organization required reforms: it was necessary to create a constitutional framework (requiring changes at the political and social level); and to rebuild the economy by moving from a centrally-planned economy to free market one. For some countries, as in the case of Ukraine and Moldova, it was also necessary to define the borders of the countries. Therefore, these countries faced the challenges associated with the simultaneousness of the changes (the co-called 'triple transition').

Most of the literature on the determinants of the type of political regime and necessary regime changes focused on broad structural factors that were thought to be conducive to either authoritarianism or democracy. The most widely studied factors of these were a series of socioeconomic conditions linked to economic development or modernization, including the level of per capita income, literacy and education, but also urbanization. According to classic modernization theory, low levels of these factors are conducive to authoritarianism, and higher levels are conducive to democracy. Because they are closely related to the level of economic development, countries are supposed to undergo a gradual, inexorable transition from authoritarianism to democracy as their economies develop (Deutsch, 1961; Burkhart and Lewis- 
Beck 1994). Table 1 presents the issues connected with the broadly-described development model, which most frequently appeared in the democratization and transition literature and which seem to be the most sensitive to change during the crisis.

Table 1. The analysed development model of East-Central European countries

\begin{tabular}{|l|l|l|}
\hline & Development model & \\
\hline Political and constitutional & Social & Economic \\
\hline $\begin{array}{l}\text { social control of the political } \\
\text { process }\end{array}$ & $\begin{array}{l}\text { social participation/civic } \\
\text { engagement } \\
\text { public trust - trust in } \\
\text { civil liberties and electoral } \\
\text { rights } \\
\text { protection of freedom of } \\
\text { speech and freedom of the } \\
\text { press }\end{array}$ & $\begin{array}{l}\text { free market } \\
\text { increase of the GDP } \\
\text { privatised and } \\
\text { private property protection }\end{array}$ \\
\end{tabular}

Based on: R. Dahl, Polyarchy: Participation and opposition, Yale University Press 1973; R. Putnam, Bowling alone: America's declining social capital, Culture and politics, Springer 2000; C. Offe, Varieties of Transition: The East European and East German Experience, MIT Press 1997; A. Smith, An Inquiry into the Nature and Causes of the Wealth of Nations, ; P. Sztompka, Zaufanie: fundament społeczeństwa, Wydawnictwo Znak, Kraków 2007; K. Skarżyńska, Aktywność i bierność polityczna, [in:] K. Skarżyńska (ed.), Psychologia polityczna, Zysk i S-ka, Poznań 1999; T. Skocpol, M. P. Fiorina, Civic Engagement in American Democracy, Brookings Institution Press 2004.

As far as the model of governing is concerned, the liberal democracy path was the preferred one. Frameworks were established for free economic trade, leaving social issues and stimulation for development of a civic society for some future time. As a result, institutions of the state - its most important part - were indeed established and functioned well, but on the lower levels old 
practices and habits from the communist period prevailed (Wołek, 2012 p. 83). Yet, contrary to common expectations they did not embrace pro-democracy and pro-market values, but were subjected to the pressure of old practices and habits from the period of democratic centralism and state monopoly of the communist era. This was a hybrid system which can be assessed by using democracy indices.

Table 2. Freedom in the World 1990-2019 ${ }^{2}$

\begin{tabular}{|l|l|l|l|l|l|l|}
\hline Year & & $\begin{array}{l}\text { Czech } \\
\text { Republic }\end{array}$ & Slovakia & Hungary & Moldova & Ukraine \\
\hline 1990 & $\begin{array}{l}\text { Political } \\
\text { Rights }\end{array}$ & 6 & 6 & 4 & $\begin{array}{l}\text { Part of } \\
\text { Union of } \\
\text { Soviet } \\
\text { Socialist } \\
\text { Republics } \\
6\end{array}$ & $\begin{array}{l}\text { Part of } \\
\text { Union of } \\
\text { Soviet } \\
\text { Socialist } \\
\text { Republics } \\
6\end{array}$ \\
\cline { 2 - 7 } & $\begin{array}{l}\text { Civil } \\
\text { Liberties: }\end{array}$ & 6 & 6 & 3 & 5 & 5 \\
\cline { 2 - 7 } & \begin{tabular}{l} 
Status \\
\cline { 2 - 7 }
\end{tabular} & not free & not free & partly free & not free & not free \\
\hline & Rights & 1 & 2 & 1 & 4 & 3 \\
\cline { 2 - 7 } & $\begin{array}{l}\text { Civil } \\
\text { Liberties: }\end{array}$ & 2 & free & free & partly free & partly free \\
\cline { 2 - 7 } & Status & free & 3 & 2 & 4 & 4 \\
\hline
\end{tabular}

\begin{tabular}{lccc}
\hline${ }^{2}$ Key: & \multicolumn{2}{c}{ Democracy Percentage } & Old Scale \\
Democracy Score & $100-66.68$ & $1.00-2.99$ \\
CD $=$ Consolidated & $5.01-7.00$ & $66.67-50.01$ & $3.00-3.99$ \\
$\begin{array}{l}\text { Democracy } \\
\text { SCD }=\text { Semiconsolidated }\end{array}$ & $4.01-5.00$ & $50.00-33.34$ & $4.00-4.99$ \\
$\begin{array}{l}\text { Democracy } \\
\text { T/H = Transitional / Hybrid }\end{array}$ & $3.01-4.00$ & $33.33-16.68$ & $5.00-5.99$ \\
$\begin{array}{l}\text { Regime } \\
\text { SCA = Semiconsolidated }\end{array}$ & $2.01-3.00$ & $16.67-0.00$ & $6.00-7.00$ \\
$\begin{array}{l}\text { Authoritarian Regime } \\
\text { CA = Consolidated }\end{array}$ & $1.00-2.00$ & & \\
Authoritarian Regime & & &
\end{tabular}




\section{NO. 34 / 2020}

\begin{tabular}{|c|c|c|c|c|c|c|}
\hline \multirow[t]{3}{*}{2000} & $\begin{array}{l}\text { Political } \\
\text { Rights }\end{array}$ & 1 & 1 & 1 & 6 & 4 \\
\hline & $\begin{array}{l}\text { Civil } \\
\text { Liberties: }\end{array}$ & 1 & 2 & 2 & 6 & 4 \\
\hline & Status & free & free & free & not free & partly free \\
\hline \multirow[t]{3}{*}{2005} & $\begin{array}{l}\text { Political } \\
\text { Rights }\end{array}$ & 1 & 1 & 1 & 3 & 4 \\
\hline & $\begin{array}{l}\text { Civil } \\
\text { Liberties: }\end{array}$ & 1 & 1 & 1 & 4 & 3 \\
\hline & Status & free & free & free & partly free & partly free \\
\hline \multirow[t]{3}{*}{2010} & $\begin{array}{l}\text { Political } \\
\text { Rights }\end{array}$ & 1 & 1 & 1 & 3 & 3 \\
\hline & $\begin{array}{l}\text { Civil } \\
\text { Liberties: }\end{array}$ & 1 & 1 & 1 & 3 & 3 \\
\hline & Status & free & free & free & partly free & partly free \\
\hline \multirow[t]{3}{*}{2015} & $\begin{array}{l}\text { Political } \\
\text { Rights }\end{array}$ & 1 & 1 & 2 & 3 & 3 \\
\hline & $\begin{array}{l}\text { Civil } \\
\text { Liberties: }\end{array}$ & 1 & 1 & 2 & 3 & 3 \\
\hline & Status & free & free & free & partly free & partly free \\
\hline \multirow[t]{3}{*}{2019} & $\begin{array}{l}\text { Political } \\
\text { Rights }\end{array}$ & 1 & 1 & 3 & 3 & 3 \\
\hline & $\begin{array}{l}\text { Civil } \\
\text { Liberties: }\end{array}$ & 1 & 2 & 3 & 4 & 4 \\
\hline & Status & free & free & partly free & partly free & partly free \\
\hline
\end{tabular}

Sources: https://freedomhouse.org/sites/default/files/2020-02/Freedom_in_the_World_19891990_complete_book.pdf; https://freedomhouse.org/report/nations-transit [Accessed 19 July 2020]

*in 1996 and 1997 Slovakia: Political Rights- 2, Civil Liberties- 4, status: partly free 
One may mention here the Freedom House (FH) index, in which the Czech Republic, Slovakia and Hungary had been shown as being at the forefront of changes for years (Table 2) (Nations in Transit 1990-2019). Therefore, we singled out the elements of the development model (Table 1) which are also taken into account in the measure of democracy quality in the FH index. This allows us to show different stages of transformation before the pandemic erupted.

In analysing the place of the examined countries in terms of the ranking of their democratic liberties (Freedom in the World), we can observe three paths of democratization. The Czech Republic and Slovakia belong to the category of free or consolidated democracies, while two countries that once belonged to the Union of Soviet Socialist Republics (USSR) - Ukraine and Moldova - are still described as partly free or hybrid regimes. Hungary has the most interesting experiences in building democracy. Over the course of the last 10 years, it lost the status of transition leader and fell in many democracy rankings. At the beginning of transition, in 1990, Hungary was the only country in the East Central European region described as partly free, as opposed to other countries which belonged to the not free category. Considering the observed decline, it is important to check how the pandemic has affected democratic liberties in the region.

Social participation is an important indicator of democratization potential in East Central Europe. It is also closely connected with the issue of trust and social capital in post-communist societies, both of which are rather low. Trust is the foundation upon which the legitimacy of public institutions is built and is crucial for maintaining social cohesion (Letki, 2004). Maintaining a robust civic sphere of numerous associations and activities is invaluable and contributes to the quality of democracy. However, the civil society in East Central Europe has been regarded as weak and not particularly engaged in social activities. Marc Howard has pointed out three major factors as responsible for the weak level of civic engagement in the post-communist democracies: the legacy of the communist mandatory membership of state-controlled organizations; the persistence of private networks of family and friends; and the overall disappointment with the democratic transformation after the collapse of communism (Howard, 2003). These factors were significant in the initial stage of transformation, but later they evolved. Yet even some decades after the transition, political trust levels remain very low (Dimitrova-Grajzl, Simon, 2010). People are less likely to engage in institutionalised political actions - contacting a politician, working for a political party or organisation - or via non-institutionalised routes such as signing a petition or 
joining a demonstration (European Social Survey, 2013). Public trust is important in democracies as it leads to greater compliance with regulations and is also necessary to increase market freedom. If we look at the trust in the government in Czech, Hungary and Slovakia we can see that it is below 50\% and also below the EU average. The development of trust in the analysed societies still requires social and institutional changes. It can be, at least partly, facilitated by successful political and economic reforms that lead to democratic consolidation and economic growth, which have so far been lacking in Ukraine and Moldova. Both these Post-USSR countries have still not reached the endpoint of becoming democratic countries (see Table 2).

Table 2. Trust in governments in 2018 and 2020* (during the pandemic)

\begin{tabular}{|l|c|c|}
\hline Country & $\mathbf{2 0 1 8}$ & $\mathbf{2 0 2 0}$ \\
\hline Czech Republic & $46.51 \%$ & $52 \% * *$ \\
\hline Hungary & $46.70 \%$ & $43,4 \%$ \\
\hline Slovakia & $48.97 \%$ & $63,6 \%$ \\
\hline Moldova & $26.47 \%$ & no data*** \\
\hline Ukraine & $10.95 \%$ & $9 \%$ \\
\hline
\end{tabular}

Source: https://ourworldindata.org; https://news.gallup.com/poll/247976/world-lowukrainians-confident-government.aspx; https://www.europarl.europa.eu/at-your-service/files/beheard/eurobarometer/2020/public_opinion_in_the_eu_in_time_of_coronavirus_crisis/exceldata/covid-19-online-survey_excel.zip [Accessed 12 August 2020]

* In case of data concerning trust it is impossible to present analogical time periods to present the values for all states - there is a lack of research that would make it possible to compare such data.

**In case of the Czech Republic, Hungary and Slovakia the questions in the survey refer to the overall support for government and reflect the answers summed up as 'totally support' and 'tend to support'.

***Moldova held parliamentary election in February 2020. In March there was an additional government reshuffle 
Also, when we look at participation in voluntary associations important for building social capital, even in comparison with other post-authoritarian states in Southern Europe and Latin America, Central Eastern Europe stands out with its "distinctly lower" figures. The OECD report shows that participation in voluntary organizations was lowest in case of Hungary and Slovakia (below $10 \%)^{3}$.

When we analyse the last issue - economic transformation - in the 1990s the choice of the free market economy was obvious. Governments often followed the recommendations of the International Monetary Fund and the World Bank in order to forget the omnipotent communist state and to choose a state playing a minimal role in the economy. Neo-liberalism won the battle, as no attempts were made at creating one's own version of a strong state supporting economic development (Amsden, Kochanowicz, Taylor, 1994, pp. 17-51, 191-199).

Regardless of the evaluation of this choice, i.e. whether it was determined by the wish to join the dominant economic model or whether it was only an imitation, we should take a closer look at its economic parameters.

Table 3. GDP growth in the analysed countries

\begin{tabular}{|l|l|l|l|l|l|}
\hline Year & Czech Republic & Slovakia & Hungary & Moldova & Ukraine \\
\hline 1990 & $0.1 \%$ & $6.2 \%(1994)$ & $-3.5 \%$ & $-17.5 \%(1991)$ & $-9.7 \%(1992)$ \\
\hline 1995 & $4.5 \%(1996)$ & $7.9 \%$ & $2.5 \%$ & $-1.4 \%$ & $-12.1 \%$ \\
\hline 2000 & $4.3 \%$ & $1.2 \%$ & $4.5 \%$ & $2.1 \%$ & $5.9 \%$ \\
\hline 2005 & $6.5 \%$ & $6.6 \%$ & $4.2 \%$ & $7.5 \%$ & $3.1 \%$ \\
\hline 2010 & $2.3 \%$ & $5.7 \%$ & $0.7 \%$ & $7.1 \%$ & $4.1 \%$ \\
\hline 2015 & $5.3 \%$ & $4.8 \%$ & $3.8 \%$ & $-0.3 \%$ & $-9.8 \%$ \\
\hline 2019 & $2.6 \%$ & $2.3 \%$ & $4.9 \%$ & $3.6 \%$ & $3.2 \%$ \\
\hline
\end{tabular}

Source: https://www.imf.org/en/Countries [Accessed 28 July 2020]

\footnotetext{
3 The question was whether respondents volunteered to work for any organization in the last year https://www.oecd.org/social/family/CO4.1-Participation-voluntary-work.pdf. The report of OECD - Social Policy Division Directorate of Employment, Labour and Social Affairs just included the Czech Republic, Slovakia and Hungary, so we cannot determine whether it was the lowest among the five analysed countries.
} 
Table 3 shows the IMF information on GDP growth since 1990, and in order to see the trends better, only the values every five years are shown ${ }^{4}$. Following the initial transformation shock, in which all the analysed countries experienced a GDP decline, in the 1990s their economies recovered. While in the Czech Republic, Slovakia and Hungary we could observe an increase of GDP in the mid-1990s, Moldova and Ukraine lag behind in this process by approximately five years. In addition, the 2007-2009 economic crisis, which started with the collapse of the markets in the USA, brought massive damages to the Post-Soviet countries. In Ukraine, the 2013 political crisis and subsequent Euromaidan 'revolution', combined with the conflict in Donbas, which started in 2014, has further drained the state's financial resources. It was only in recent years that some economic revival has been observed (Iwański, 2017). Moldova had problems with implementing the needed reforms and therefore did not receive the aid expected from international financial organizations, important for its economy to survive. This has resulted in further economic regress in this small country, which relies very much on external funds (Całus, 2016).

\section{The pandemic and the development model - the empirical evidence}

\section{$\underline{\text { Politics }}$}

While Democracies have reacted to the pandemic in various ways, nevertheless in all the analysed countries states of emergency were implemented, which included, among others, the temporary limitation of civil rights and undermining the principles of democratic governance. Freedom of association, freedom of speech and movement, or the right to equal education were suspended for the sake of national security. However, they should be used only in extraordinary circumstances, which are clearly defined in the legal assumptions of the country (Gebethner, 1982).

Following the Varieties of Democracy (V-Dem, 2020) projects, we can distinguish six types of violations of democratic standards implemented as emergency measures during the Covid19 pandemic. V-Dem data has shown that three of them in particular - restrictions on media freedom; discriminatory measures; and disproportionate limitations on the role of the legislature have been most often violated in the analysed countries (see Table 4).

\footnotetext{
${ }^{4}$ Admittedly, we were not always able to show full data for the selected years - this, however, is not of major significance, as our main goal was to show trends.
} 
Table 4. Pandemic Democratic Violations (based on V-Dem six indicators)

\begin{tabular}{|c|c|c|c|c|c|c|}
\hline & Indicators & $\begin{array}{l}\text { Czech } \\
\text { Republic }\end{array}$ & Slovakia & Hungary & Moldova & Ukraine \\
\hline & $\begin{array}{l}\text { time of emergency } \\
\text { response }\end{array}$ & $\begin{array}{l}2020-03-12- \\
2020-05-17\end{array}$ & $\begin{array}{l}2020-03-16 \\
2020-06-13\end{array}$ & $\begin{array}{l}2020-03-11- \\
2020-06-17\end{array}$ & $\begin{array}{l}2020-03-17- \\
2020-05-15\end{array}$ & $\begin{array}{l}2020-03-25 \\
2020-04-24\end{array}$ \\
\hline 1 & $\begin{array}{l}\text { No time limit on } \\
\text { emergency measures }\end{array}$ & no violation & no violation & $\begin{array}{l}\text { minor } \\
\text { violation }\end{array}$ & no violation & no violation \\
\hline 2 & Discriminatory measures & no violation & $\begin{array}{l}\text { major } \\
\text { violation }\end{array}$ & no violation & no violation & no violation \\
\hline 3 & $\begin{array}{l}\text { De-jure violation of non- } \\
\text { derogable rights from the } \\
\text { ICCPR* }\end{array}$ & no violation & no violation & no violation & no violation & no violation \\
\hline 4 & $\begin{array}{l}\text { Restrictions on media } \\
\text { freedom** }\end{array}$ & $\begin{array}{l}\text { minor } \\
\text { violation }\end{array}$ & no violation & $\begin{array}{l}\text { major } \\
\text { violation }\end{array}$ & $\begin{array}{l}\text { major } \\
\text { violation }\end{array}$ & $\begin{array}{l}\text { major } \\
\text { violation }\end{array}$ \\
\hline 5 & $\begin{array}{l}\text { Disproportionate } \\
\text { limitations on the role of } \\
\text { the legislature }\end{array}$ & no violation & no violation & $\begin{array}{l}\text { Some } \\
\text { violation }\end{array}$ & no violation & no violation \\
\hline 6 & Abusive enforcement & no violation & no violation & no violation & no violation & no violation \\
\hline
\end{tabular}

*International Covenant on Civil and Political Rights

** information on media censorship in 2019 from the V-Dem data set in order to account for structural limitations of media freedom.

\section{Restrictions on media freedom}

One disturbance in Pandemic Democratic Violations concerns limitations on access to information. There are a few isolated reports of the governments or government officials limiting media access to Covid-19-related information, but these were not systematic or ongoing.

In the Czech Republic, journalists were initially not allowed to be present at press conferences based on public health grounds, except for public media and two private TV stations. Later on journalists were allowed to participate in press conferences remotely through video conferencing (RSF, 2020).

In Hungary, the emergency measures have put strict de-jure limitations on how the media could report on Covid-19. These provisions are not limited to stopping the spread of disinformation on Covid-19, but include any reporting on Covid-19, such as the prevalence of the virus and the 
government response. According to the Coronavirus Protection Act, spreading misinformation can be punishable with up to 5-year jail sentence.

In Moldova, the emergency measures de-jure allow the government to put some limitations on how the media can report on Covid-19. These provisions are explicitly limited to stopping disinformation on Covid-19, such as closing news websites that misreport on the origins or how the disease spreads. In Moldova media outlets are obliged to only use information on Covid-19 from the competent public authorities, in order to limit disinformation. In Ukraine, there were a few incidents which contained a limitation on media freedom. For example, the police aggressively pushed and broke the camera equipment of a journalist reporting on anti-lockdown protests on 29 April 2020. In other place, journalists had to leave a council meeting on 18 March (on the topic of the local budget) based on public health grounds (ICNL, 2020; The Audiovisual Council of the Republic of Moldova, 2020).

\section{Discriminatory measures}

The emergency measures have affected some groups' democratic rights and freedoms disproportionately. Democratic rights and freedoms are defined as freedom of movement, assembly, association, and expression. Infringements include, for instance, quarantines for specific social groups without an explicit virologic basis. In Slovakia, mandatory targeted testing and quarantines were introduced by government resolution for the Roma communities. Five Roma settlements were placed under quarantine by the military, despite a lower infection threshold for introducing a quarantine ( 1 percent) than established by government rules (10 percent) (Thoompail, 2020). Moreover, according to the available evidence the authorities did not put in place adequate provisions of food and medical supplies (Amnesty International, 2020).

\section{Disproportionate limitations on the role of the legislature}

The parliament has a key legislative role in a democratic state. This right can be passed on to the executive power only for the time specified in the constitution and in strict accordance with other legal provisions that may result from the constitution. The use of "rule by decree" introduced in Hungary enables the government to pass laws without the approval of the legislature. Therefore, the executive branch has the right to rule by decree on many issues, which may exceed actual 
Covid-19 related issues due to the vague formulation in the emergency laws (IPU, 2020; Gall, 2020).

\section{$\underline{\text { Social Trust }}$}

Public trust in the government's ability to manage the pandemic is crucial as it underpins public attitudes and behaviours during the time of pandemic. The success of governmental social control depends more on voluntary compliance than on government enforcement. We may wonder whether greater trust, apart from institutional solutions and economic activities, is a factor increasing the effectiveness of the fight against the pandemic. At the same time, we should also ask whether the actions of a government during the pandemic increased or decreased the level of trust. Most political systems in East Central Europe continue to be plagued by political instability and endemic levels of corruption (Tavits, 2008). In the communist times citizens of the analysed countries distrusted their non-democratic governments. However, in contemporary times it seems that trust no longer can be clearly broken down into regime types (Kleinfeld, 2020).

In a few cases, like in the Czech Republic and Slovakia, we could observe (Table 2) that trust in government increased during the pandemic. This is consistent with the trends that were visible also in many Western European countries, when at the outbreak of the pandemic there was a significant growth in the approval for government decisions. A decline of trust in the government was seen in Hungary and Ukraine, and in the latter case trust in those in power before Covid-19 was already one of the lowest in Europe (Bikus, 2020). In Hungary restrictive limitations were introduced and, most importantly, the prime minister's powers increased at the cost of the parliament for an indefinite period, which decreased public trust.

Just before the pandemic, Moldova held parliamentary elections and in March 2020 there were also some changes in the government. A similar governmental crisis was in place in Ukraine. The lack of political stability which characterizes Post-Soviet countries, often accompanied by a high level of corruption (Moldova occupies $120^{\text {th }}$ place in the corruption perception index, while Ukraine is in $126^{\text {th }}$ place ${ }^{5}$ ) is also reflected in democracy rankings. These two factors (lack of stability and corruption) might have contributed to the low level of trust enjoyed by incumbent

\footnotetext{
${ }^{5}$ The ranking comprises 198 countries $-1^{\text {st }}$ place means that corruption is the lowest. The higher the ranking, the more serious problems corruption poses, see https://www.transparency.org/en/cpi/2019/results/ukr [Accessed 12 July 2020]
} 
government, ${ }^{6}$ and this explains the widely-varying evaluations of their actions during the pandemic.

As an analysis conducted by the European Social Survey suggests that lower participation rates in post-communist regimes can be explained by the political practices of those countries such as a lack of good governance; continuing high levels of corruption; and relatively poor economic performance (European Social Survey, 2013). All of this can reduce trust and discourage people from engaging with politics. It suggests that citizens' engagement is likely to remain low unless future governments are able to improve their performance. During the pandemic in countries which had higher levels of trust in state institutions, governments could rely more on warnings, suggestions and regulations rather than on such severe measures as curfews or high fines (Walecka, Wojtas, 2020).

\section{The Economy}

If we want to check how the pandemic affected the free market economy model adopted in the analysed countries, we can only rely on forecasts, as up-to-date data is still unavailable

Table 6. The anticipated decline in GDP as a result of Covid-19

\begin{tabular}{|l|l|l|l|l|l|}
\hline & Czech Republic & Slovakia & Hungary & Moldova & Ukraine \\
\hline $\begin{array}{l}2019 \text { GDP } \\
\text { growth }\end{array}$ & $2.6 \%$ & $2.3 \%$ & $4.9 \%$ & $3.6 \%$ & $3.2 \%$ \\
\hline forecast & $-6.5 \%$ & $-6.2 \%$ & $-3.1 \%$ & $-3 \%$ & $-7.7 \%$ \\
\hline $\begin{array}{l}\text { Difference } \\
\text { between GDP } \\
\text { growth in 2019 } \\
\text { and forecasted } \\
\text { decline }\end{array}$ & $9.1 \%$ & $8.5 \%$ & $8.0 \%$ & $6.6 \%$ & $10.9 \%$ \\
\hline
\end{tabular}

Source: https://www.imf.org/en/Countries [Accessed 15 September 2020]

\footnotetext{
${ }^{6}$ Seventy-eight percent of Moldovans believe that their country is governed in the interest of some people, and only $14 \%$ think that it is governed in interest of the majority of people. At the same time, the Church enjoys more trust from citizens in Moldova than any other body. The Orthodox Church in Moldova has denounced the potential use of a vaccine against COVID-19, calling it a satanic plan to microchip people, or introduce other foreign devices into the human body, see: https://balkaninsight.com/2020/05/20/moldovan-church-denounces-covid-vaccine-as-anti-christian-plot/ [Accessed 15 July 2020]
} 
As the forecasts on GDP changes show (Table 6), the countries of the region are faced with a projected large economic decline. The difference between the GDP growth last measured in 2019 and the forecasts of GDP decline in 2020 ranged from $-6.6 \%$ in Moldova to $-10.9 \%$ in Ukraine (Olchowski, 2020; Iwański, Matuszak, Żochowski, 2020)7. The governments reacted to this situation offering support for entrepreneurs, employees, or special packages for those working in the healthcare sector. The Czech Republic allocated the largest amount of financial means for such interventions - over 8 billion euro (Table 7), while Moldova - the poorest country - encountered the most acute problems. In analysing the nature of government aid we can notice that all countries, in spite of operating in the paradigm of a free market economy, took some actions in the spirit of social solidarity. It was presumed that a decline in the level of citizens' financial security would lead to social discontentment, which can be translated into declining support for incumbents. The common feature of the adopted aid measures was support for entrepreneurs and self-employed persons - exempting them from social insurance dues and some taxes so that they could survive the lockdown.

Table 7. Anti-crisis shields and their effect on the free market and ownership rights

\begin{tabular}{|c|c|}
\hline & Fiscal solutions \\
\hline Czech Republic & $\begin{array}{l}\text { fiscal package in the amount of CZK } 233.7 \text { billion (EUR } 8.8 \\
\text { billion, } 4.2 \% \text { of GDP); } \\
\text { payment of } 80 \% \text { of remuneration for employees in quarantine; } \\
\text { - } \quad \text { abolishing social insurance premiums paid by employers } \\
\text { lowering the VAT rate (from } 15 \% \text { to } 10 \% \text { ) on selected services } \\
\text { (accommodation, culture, sport); } \\
\text { paying } 50 \% \text { of the rent paid by entrepreneurs; } \\
\text { bonuses for social and healthcare service workers in the total } \\
\text { amount of CZK } 16.5 \text { billion; } \\
\text { corporations for the } 2^{\text {nd }} \text { quarter of } 2020 \text {. }\end{array}$ \\
\hline
\end{tabular}

\footnotetext{
${ }^{7}$ In Moldova at the end of the first decade of $21^{\text {st }}$ century money transfers from emigrants accounted for a third of the country's GDP. In Ukraine, transfers from emigrants are also an essential element of the whole GDP - in 2019, as bank transfers alone emigrants sent nearly USD 12 billion to Ukraine, which accounts for approximately $9 \%$ of its GDP.
} 


\begin{tabular}{|c|c|}
\hline Slovakia & $\begin{array}{l}\text { - } \quad \text { package for healthcare services - EUR } 1.7 \text { billion; } \\
\text { financial support for enterprises and self-employed persons; } \\
\text { increased unemployment benefits and sickness and care } \\
\text { allowances; } \\
\text { insurance premiums for entrepreneurs; }\end{array}$ \\
\hline Hungary & $\begin{array}{l}\text { aid package: HUF } 245 \text { billion (EUR } 0.71 \text { billion)+ (EUR } 1.31 \\
\text { billion - HUF } 450 \text { billion for investments); } \\
\text { in sectors affected by covid-19 social insurance premiums were } \\
\text { abolished and in other sectors - lowered until the } 30^{\text {th }} \text { of June; } \\
\text { (mainly in the service sector) were exempted from tax } \\
\text { a the media received tax relief due to losses incurred in } \\
\text { advertising revenue; } \\
\text { granting loans with paid interest and guarantees to Hungarian } \\
\text { companies; } \\
\text { - zero-interest loans to small and medium-sized enterprises }\end{array}$ \\
\hline Moldova & $\begin{array}{l}\text { - } \quad \text { support for enterprises and households in a difficult situation, } \\
\text { widening unemployment benefits } \\
\text { government, } \\
\text { tax relief for sectors affected by restrictions imposed by the } \\
\text { postponing payment of taxes until the middle of } 2020\end{array}$ \\
\hline Ukraine & $\begin{array}{l}\text { UAH } 64.669 \text { billion (EUR } 1.99 \text { billion) for the pandemic fund; } \\
\text { resignation from property taxes, land taxes and penalty } \\
\text { assessments as of March } 2020 \text {; } \\
\text { 19 patients and social insurance against illness } \\
\text { increasing retirement pensions; } \\
\text { medicines, medical and other equipment used in the fight } \\
\text { against Covid-19 was exempted from custom duties and the VAT tax; } \\
\text { introducing price regulations for the quarantine period for } 10 \\
\text { food products of social importance, } 20 \text { categories of individual } \\
\text { protection and medicine products, and over } 10 \text { types of antiseptic } \\
\text { products. }\end{array}$ \\
\hline
\end{tabular}

Sources:https://www.imf.org/en/Topics/imf-and-covid19/Policy-Responses-to-COVID19; https://covidlawlab.org/ [ Accessed 20 July 2020]

It is worth noting that in the Czech Republic and Ukraine healthcare sector workers and people involved in the fight with the pandemic received significant pay rises. One should also note 
the clearly anti-free market solution adopted in Ukraine, namely the introduction of official prices for the quarantine period.

\section{Discussion and conclusions}

It is impossible at this time to unequivocally assess the responses to the pandemic and changes in the development model. The violations of democratic principles can be divided into two categories: those interfering with the rights and liberties of citizens, but not affecting the chosen development path; and those complementing the processes of building hybrid (nondemocratic) regimes which were initiated before the pandemic. This means that while in the Czech Republic and Slovakia the liberal democracy model has not been questioned, in Hungary the earlier tendencies of backsliding from democracy have deepened. In the countries which are in the process of democracy-building - Moldova and Ukraine - the pandemic has not significantly affected the intensity of violating its principles, as they are still weakly established. Neither however, has it caused a reversal from the earlier development path.

If we look at the violations of media freedom it can be noted that the pandemic did not except in the cases of Hungary and Slovakia - bring about a major change. Hungary has fallen from $84^{\text {th }}$ to $89^{\text {th }}$ place in the World Press Freedom Index, which means a decline in media freedom (World Press Freedom Index 2019, 2020), while Slovakia has improved its position during the pandemic by five places in the index. The second most frequent violation of democratic principles was the deterioration of the status of minorities and engaging in discriminatory actions against them. This has mainly concerned the Roma minority in Slovakia. Apart from the social changes, countries of the region have faced a huge economic decline (due to lockdown) and all governments have offered support for entrepreneurs, employees, and special packages for people working in the healthcare sector. The scale of government support in each case differs (see Table 7). The common feature of the state intervention in the free market, puts some limits on economic freedom.

In countries with consolidated democracies, which according to Freedom House (Nation in Transit Project) included the Czech Republic and Slovakia in 2019, a slight decline was observed in 2020, whereas in hybrid regimes - Moldova and Ukraine - an equally minor improvement could be observed. However, in both cases this did not change the classification of these systems within their categories. Only Hungary - described as a "coronavirus autocracy" witnessed a change in its classification. Starting from 2015 Hungary fell from the category of 
consolidated democracies to semi-consolidated ones, and the pandemic brought with it further anti-democratic changes. So one can argue in this case that Covid-19 has strengthened the development path chosen by the Orban's government and allowed for further movement towards autocracy. Currently, Hungary is only three points away from Ukraine in the democracy ranking index. Ukraine has never been regarded in FH index as a partly consolidated democracy, and its highest place was $46^{\text {th }}$ (in the years 2006-2008) (Nations in Transit, 2006-2008).

It thus seems that an analysis of the pandemic as a catalyst of non-democratic tendencies is not clear-cut. We need to bear in mind that we are relying on data generated during the crisis itself, and that we will be able to discern fundamental changes only after a certain period of time. It should also be noted that all analysed countries introduced states of emergency - which means that actions limiting the right to assemble or the right to free movement were imposed in accordance with the constitution.

Post-communist societies demonstrate a low level of trust in their governments' activities, and only in two cases - Slovakia and the Czech Republic - can we note some minor improvement. In other countries we have witnessed the decline of trust enjoyed by those in power as a result of the implementation of "covid laws".

To conclude, the Covid-19 pandemic has not been a catalyst for change in the development model of the analysed countries. It has only deepened/strengthened the changes and trends that existed before the crisis, not brought about any significant change, or in some cases just brought some corrections to the development path. In a similar way Ivan Krastev argues that the coronavirus pandemic might only strengthen some tendencies, but it is not a disruptive factor (Krastew, 2020), which in our analysis can be confirmed in the case of Hungary. The other analysed states remain on the development paths they had chosen before the pandemic. Obviously, due to the timing of the publication of this paper - the pandemic is still going strong - we cannot draw firm conclusions concerning future changes to the development models.

\section{References}

1. Amnesty International (2020) Stigmatizing Quarantines of Roma Settlements in Slovakia and

Bulgaria, 
https://www.amnesty.org/download/Documents/EUR0121562020ENGLISH.PDF [Accessed 20 July 2020]

2. Amsden, A. H., Kochanowicz, J., Taylor, L. (1994) The Market Meets its Match: Restructuring the Economies of Eastern Europe, Cambridge MA: Harvard University Press.

3. Bikus, Z. (2020) World-Low 9\% of Ukrainians Confident in Government https://news.gallup.com/poll/247976/world-low-ukrainians-confident-government.aspx [Accessed 20 July 2020]

4. Burkhart, R.E., Lewis-Beck, M.S. (1994) Comparative democracy: The economic development thesis, The American Political Science Review, 88 (4), pp. 903-910.

5. Całus, K. (2016) Mołdawia: od pluralizmu oligarchicznego do hegemonii Plahotniuca, Komentarze OSW, https://www.osw.waw.pl/pl/publikacje/komentarze-osw/201604-11/moldawia-od-pluralizmu-oligarchicznego-do-hegemonii [Accessed 22 June 2020]

6. Dahl, R. (1973) Polyarchy: Participation and opposition, Yale University Press.

7. Deutsch, K.W. (1961) Social mobilization and political development, The American Political Science Review, 55 (3), pp. 493-514.

8. Dimitrova-Grajzl, V.P, Simon, E. (2010) Political Trust and Historical Legacy: The Effect of Varieties of Socialism, East European Politics \& Societies, 24(2), pp. 206-228.

9. European Social Survey (2013), Exploring public attitudes, informing public policy. Selected findings from the first five rounds, https://www.europeansocialsurvey.org/docs/findings/ESS1_5_select_findings.pdf [Accessed 20 July 2020]

10. Gall, L. (2020) Hungary's Orban Uses Pandemic to Seize Unlimited Power Emergency Draft Law A Clear Threat to Democratic Freedoms, Human Rights Watch, https://www.hrw.org/news/2020/03/23/hungarys-orban-uses-pandemic-seize-unlimited-power [Accessed 20 July 2020]

11. Gebethner, S. (1982) Stany szczególnego zagrożenia jako instytucja prawa konstytucyjnego, Państwo i Prawo, 8, pp. 9-15.

12. Howard, M.M. (2003) The Weakness of Civil Society in Post-Communist Europe, Cambridge: Cambridge University Press.

13. International Center For Non-For-Profit Law ICNL., Covid -19 Civic Freedom Tracker, https://www.icnl.org/covid19tracker/?location=81\&issue=\&date=\&type=[Accessed 24 
July 2020]

14. Inter-Parliamentary-Union (IPU) (2020) Hungary. Country compilation of parliamentary responses to the pandemic, https:/www.ipu.org/country-compilationparliamentary-responses-pandemic\#H [Accessed 15 July 2020]

15. Iwański, T, Matuszak, S., Żochowski, P. (2020) Perspektywy rozwoju pandemii COVID-19 na Ukrainie, Komentarze OSW, 323, https://www.osw.waw.pl/pl/publikacje/komentarze-osw/2020-03-27/perspektywy-rozwojupandemii-covid-19-na-ukrainie [Accessed 15 September 2020]

16. Iwański, T. (2017) Stabilny kryzys. Gospodarka Ukrainy trzy lata po Majdanie, Komentarze OSW, 235 https://www.osw.waw.pl/pl/publikacje/komentarze-osw/2017-0405/stabilny-kryzys-gospodarka-ukrainy-trzy-lata-po-majdanie [Accessed 22 June 2020]

17. Kleinfeld, R. (2020) Do Authoritarian or Democratic Countries Handle Pandemics Better? March https://carnegieendowment.org/2020/03/31/do-authoritarian-or-democraticcountries-handle-pandemics-, better-pub-81404 [Accessed 28 June 2020]

18. Krasnodębski, Z. (2005) Demokracja peryferii, Warszawa: Słowo/Obraz Terytoria.

19. Krastew, I. (2020) Is It Tomorrow Yet?: Paradoxes of the Pandemic, Allen Lane.

20. Kriesi, H., Hutter, S. (2019) Crises and the Transformation of the National Political Space in Europe, in: Hutter, S., Kriesi, H. (eds.) European party politics in times of crisis, Cambridge: Cambridge University Press.

21. Marciniak,W. (2004) Rozgrabione Imperium. Upadek Zwiazku Sowieckiego i powstanie Federacji Rosyjskiej, Kraków: Arcana.

22. Nations in Transit, Reports 2006-2008, https://freedomhouse.org/report/nationstransit [Accessed 24 July 2020]

23. OECD - Social Policy Division - Directorate of Employment, Labour and Social Affairs, https://www.oecd.org/social/family/CO4.1-Participation-voluntary-work.pdf [Accessed 23 July 2020]

24. Offe, C. (1997) Varieties of Transition: The East European and East German Experience, Cambridge: MIT Press.

25. Olchowski, J. (2020) Mołdawia wobec pandemii COVID-19, Komentarze Instytutu Europy Środkowej (50/2020), https://ies.lublin.pl/komentarze/moldawia-wobec-pandemii-covid19-147-50-2020 [Accessed 15 September 2020] 
26. Putnam, R. (2000) Bowling alone: America's declining social capital, Culture and politics: Springer.

27. RSF. Reporters without Borders (2020) COVID-19 and press freedom: Europe must oppose measures proposed by Viktor Orbán, https://rsf.org/en/news/covid-19-and-pressfreedom-europe-must-oppose-measures-proposed-viktor-orban [Accessed 23 July 2020]

28. Skarżyńska, K. (1999) Aktywność i bierność polityczna, [in:] K. Skarżyńska (ed.), Psychologia polityczna, Poznań: Wydawnictwo Zysk i S-ka.

29. Skocpol T., Fiorina M. P. (2004) Civic Engagement in American Democracy, Washington D.C.: Brookings Institution Press.

30. Smith, A. (1994) An Inquiry into the Nature and Causes of the Wealth of Nations, Indianapolis: Liberty Fund Inc.

31. Stark, D., Bruszt, L. (1998) Postsocialist Pathways. Transforming Politics and Property in East Central Europe. Cambridge: Cambridge University Press.

32. Sztompka, P. (2007) Zaufanie: fundament społeczeństwa, Kraków: Wydawnictwo Znak.

33. Tavits, M. (2008) Representation, Corruption, and Subjective Well-Being. Comparative Political Studies, 4, pp. 1607-1630.

34. The Audiovisual Council of the Republic of Moldova, DISPOZIȚIE nr.02 din 24.03.2020 http://www.audiovizual.md/files/Dispozitie\%20CA.semnat.pdf [Accessed 20 July 2020]

35. Thoompail, M. (2020) Targeted COVID-19 testing in Roma settlements in Slovakia - A positive measure or further stigmatization?, Minority Rights Groups International, https://minorityrights.org/2020/06/02/roma-slovakia-covid-testing/ [Accessed 20 July 2020]

36. V-Dem (2020) Pandemic Backsliding: Democracy During COVID-19, https://www.v-dem.net/en/analysis/PanDem/ [Accessed 30 July 2020]

37. Wagener H.J. (2001) The Welfare State in Transition Economies and Accession to the EU, EUI Working Paper RSC 1.

38. Walecka, K, Wojtas, K. (2020) Lockdown demokracji w czasach pandemii COVID19, Raport Fundacja Konrada Adenauera 2020, https:/www.kas.de/pl/web/polen/einzeltitel//content/lockdown-demokracji-w-czasach-pandemii-covid-19 [Accessed 28 September 2020]

39. Wołek, A. (2012) Stabe państwo, Kraków-Warszawa: OMP. 
40. World Press Freedom Index 2019, Reporters without Borders, https://rsf.org/en/ranking/2020 [Accessed 28 August 2020] 